Bangladesh J. Plant Taxon. 24(2): 205-214, 2017 (December)

(C) 2017 Bangladesh Association of Plant Taxonomists

\title{
TAXONOMIC VARIATION AMONG SCHINUS MOLLE L. PLANTS ASSOCIATED WITH A SLIGHT CHANGE IN ELEVATION
}

\author{
Abeer Al-Andal, Mahmoud Moustafa ${ }^{1,2}$ and Suliman Alruman ${ }^{1}$ \\ Department of Biology, College of Science, King Khalid University, \\ Abha, Kingdom of Saudi Arabia \\ Keywords: RAPD; ISSR; Mixed RAPD; Schinus molle L.
}

\begin{abstract}
This study examined the degree of variations in DNA fingerprints associated with slight altitudinal change of Schinus molle grown in Abha region, Saudi Arabia. Seven populations from Schinus molle plants located at 2193.0, 2246.0, 2197.7, 2441.0, 2372.0, 2250.6 and 2175.0 meters had been investigated. The degree of genetic variability was evaluated using random amplified polymorphic DNA (RAPD), mixed RAPD and intersimple sequence repeat markers (ISSR). The genetic similarity coefficients from RAPD analysis revealed the maximum similarity value $(89.9 \%)$ was between population at $2250.6 \mathrm{~m}$ and population at $2175.0 \mathrm{~m}$. The genetic similarity coefficients from mixed RAPD primers displayed the highest similarity value (87.6\%) between population at $2246.0 \mathrm{~m}$ and population at $2197.7 \mathrm{~m}$. Similarity coefficients from ISSR analysis revealed the highest similarity value (86.2\%) among populations at $2193.0 \mathrm{~m}, 2246.0 \mathrm{~m}$, $2441.0 \mathrm{~m}$ and at $2250.6 \mathrm{~m}$. Super tree analysis (RAPD + mixed RAPD + ISSR) showed the highest similarity value (85.5\%) between population at $2441.0 \mathrm{~m}$ and population at $2250.6 \mathrm{~m}$. In conclusion, marker systems including RAPD, mixed RAPD and ISSR, alone or combined can be effectively used in determining the genetic relationship among Schinus molle plants even at very close populations.
\end{abstract}

\section{Introduction}

Abha region has a specialized environmental condition among all other areas in the Kingdom of Saudi Arabia which have an indirect effect on the weed plants growth. S. molle plants (family, Anacardiaceae) are among the most common weed in Saudi Arabia especially in Tharawat Mountains. The tree of $S$. molle plant is an evergreen, dioecious, grows up to 20 meters in height. Flowers are small, with yellowish white petals and all plant parts especially fruits having strong aroma (Lim, 2012). S. molle is common weed in South America and recently into many tropical and subtropical countries (Olafsson et al., 1997). In Abha region, S. molle tree has been planted in many areas as in valleys, public gardens and for house decorations. After that, the plant became a common weed in many areas of Abha city growing beside road and next the wall of houses as it is reproduced by seeds. $S$. molle plant showed to be resistant to the harsh environmental condition such as high temperature, cold and increasing soil salinity (Lim, 2012). In addition, S. molle plants usually used for the restoration of degraded areas and showed tolerance to heavy metals (Doganlar et al., 2012; Pereira et al., 2016). Toward this approach examine the genetic diversity of $S$. molle plant is highly needed as no reports available.

In recent years, a number of randomly amplified polymorphic DNA-polymerase chain reaction (RAPD-PCR) and inter-simple sequence repeat-polymerase chain reaction (ISSR-PCR) markers had been used to study genetic diversity among plant species. For example, RAPD

\footnotetext{
${ }^{1}$ Corresponding author. Email: mfmostfa@kku.edu.sa

${ }^{1}$ Research Center for Advanced Materials Science (RCAMS), King Khalid University, Abha, Saudi Arabia.

${ }^{2}$ Department of Botany, Faculty of Science, South Valley University, Qena, Egypt.
} 
technique was successfully applied genetically to distinguish among Ocimum spp. (Vieria et al., 2003), to study the genetic diversity in Monodora myristica (Uyoh et al., 2014) and various population of Ziziphus spina-christi L. (Moustafa et al., 2016). ISSR technique was used to study genetic diversity of the Lens spp. (Fikiru et al., 2007), and genetic relationships of Chukrasia spp. (Wu et al., 2014).

Therefore, the aim of this research is to study genetic diversity of $S$. molle plants growing at close locations in Abha region, KSA. To the best of our knowledge, there are few reports indicating the use of mix primer to estimate the genetic diversity among plant /or to study plant DNA fingerprint. Therefore, this study also aimed to check the status of DAN fingerprints using mixed primers.

\section{Materials and Methods}

\section{Plant material}

Seven locations at various elevations in Abha region, KSA,include 2193.0, 2246.0, 2197.7, 2441.0, 2372.0, 2250.6 and 2175.0 meters have been selected (Fig. 1). At each site, random samples of young fresh leaves from $S$. molle trees having a height $1500 \mathrm{~cm}$ had been collected.

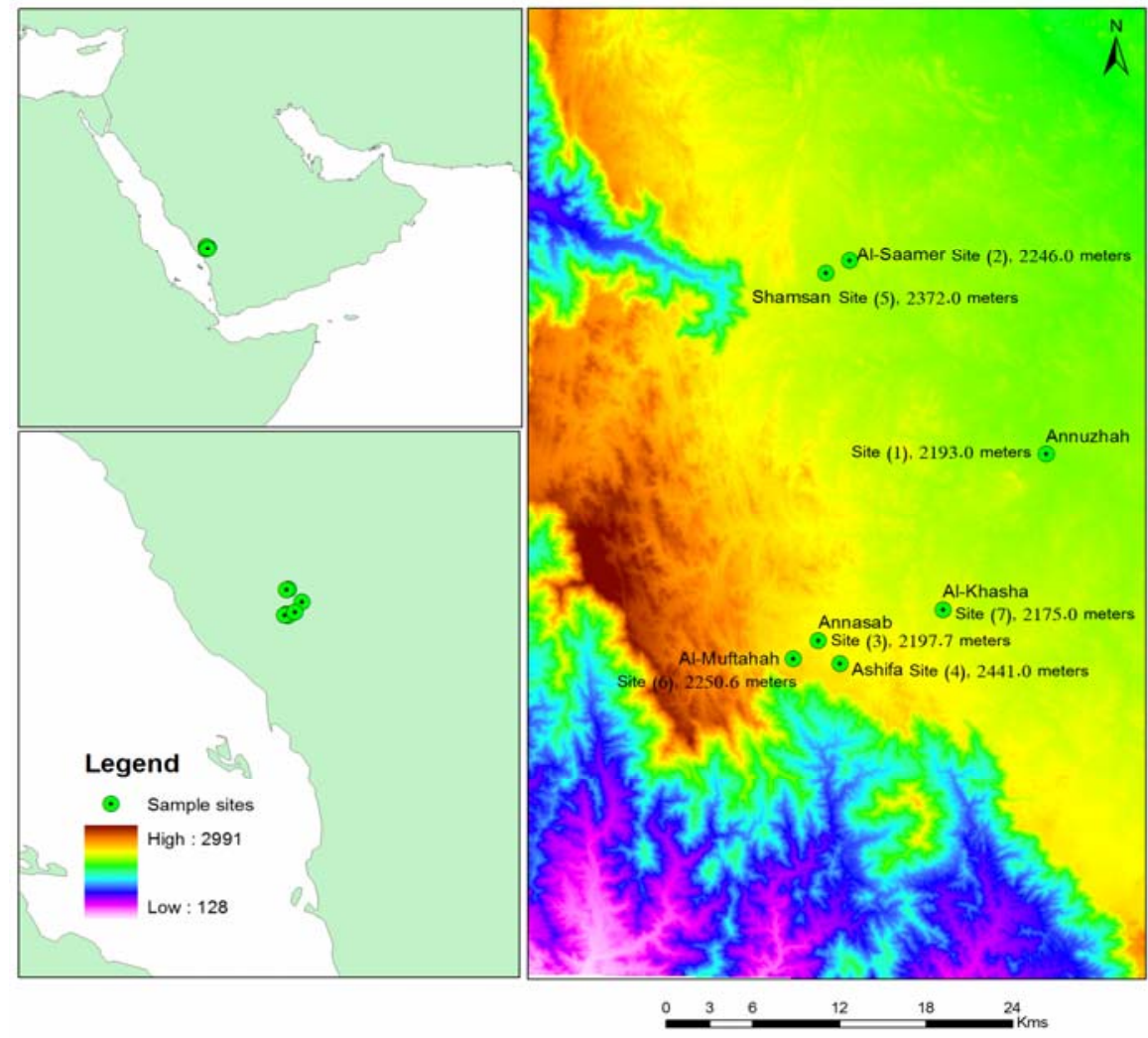

Fig. 1.Sampling sites in Abha region, KSA. Site (1), (2193.0); Site (2), (2246.0); Site (3), (2197.7); Site (4), (2441.0), Site (5), (2372.0), Site (6), (2250.6) and Site (7), (2175.0 m). 
Extraction the genomic DNA from leaves of S. molle plants

Genomic DNA was extracted from fresh young leaves of S. molle plants by using DNeasy plant mini kit. DNA concentration was estimated by a Thermo Scientific ${ }^{\mathrm{TM}}$ BioMate 3S UVVisible at $260 \mathrm{~nm}$.

\section{PCR amplification}

Eight RAPD, nine ISSR and eight mixed RAPD markers were used in this study (Table 1). PCR reaction consists from 1 X GoTaq Green Master Mix, $4 \mu \mathrm{l}$ from each primer, $20 \mathrm{ng}$ of genomic DNA and nuclease-free water to get a final $25 \mu$ l volume. PTC 200 Peltier Thermal Cycler (MJ Research - USA) adjusted as follows: Initial degree at $94^{\circ} \mathrm{C}$ for 5 minutes followed by forty nine cycles at $92^{\circ} \mathrm{C}$ for 1 minute, primer annealing temperature at $29^{\circ} \mathrm{C}$ for 1 minute, extension at $72^{\circ} \mathrm{C}$ for 2 minutes and final process for primer extension at $72^{\circ} \mathrm{C}$ for 7 minutes. An equal amount of each amplified product of 20 ul was separated by electrophoresis using $1.3 \%$ agarose gels in 0.5X TBE buffer. Stained gel with ethidium bromide was photographed by gel documentation system using UV transilluminator at $365 \mathrm{~nm}$ (Hashemi et al., 2009). Each experiment was repeated three times and molecular weight of RAPD-PCR, mixed RAPD-PCR and ISSR-PCR fragments were estimated using marker $1 \mathrm{~kb}$ DNA ladder between 250 to 10,000 bp.

Table 1. RAPD, mixed RAPD and ISSR primers.

\begin{tabular}{ll}
\hline RAPD primers & Sequence of primer (5' - 3') \\
\hline Oligo 342 & GAGATCCCTC \\
Oligo 345 & GCGTGACCCG \\
Oligo 349 & GGAGCCCCCT \\
Oligo 33 & CCGGCTGGAA \\
OPK-8 & GAACACTGGG \\
OPJ-1 & CCCGGCATAA \\
Oligo 214 & CATGTGCTTG \\
Oligo 213 & CAGCGAACTA \\
Mixed RAPD primers & Sequence of primer (5' - 3') \\
Oligo 203+Oligo 342 & CACGGCGAGT+GAGATCCCTC \\
Oligo 203+ Oligo 345 & CACGGCGAGT+GCGTGACCCG \\
Oligo 203+Oligo 42 & CACGGCGAGT+TTAACCCGGC \\
Oligo 203+Oligo 349 & CACGGCGAGT+GGAGCCCCCT \\
Oligo 203+Oligo 214 & CACGGCGAGT+CATGTGCTTG \\
Oligo 203+Oligo 213 & CACGGCGAGT+CAGCGAACTA \\
Oligo 203+Oligo 33 & CACGGCGAGT+CCGGCTGGAA \\
Oligo 203+OPK-8 & CACGGCGAGT+GAACACTGGG \\
ISSR primers & Sequence of primer (5' - 3') \\
Primer (3) & TGGATGGATGGATGGA \\
Primer (4) & CACACACA CACACA AG \\
UBC 823 & TCT CTC TCT CTC TCC \\
UBC 824 & TCT CTC TCT CTC TCG \\
UBC 826 & ACA CAC ACA CAC ACC \\
HB 14 & CTC CTCCTC GC \\
Primer (1) & GAGAGAGAGAGAGAGAC \\
Primer (2) & GAGAGAGAGAGAGAGAGAGAG \\
HB 11 & GTG TGT GT GTGTCC \\
\hline & \\
\hline
\end{tabular}




\section{Data analysis}

All scored fragments gained from RAPD-PCR, mixed RAPD-PCR and ISSR-PCR were manually recorded as present (1) or absent (0). Matrix of similarity based on binary-double zerosS3, and squared Euclidean distance was used to calculate the distances and to generate dendrogram (Sneath and Sokal, 1973). Polymorphism percentage was estimated by calculating polymorphic bands/total number of bands.

\section{Results}

RAPD analysis

RAPD primers produced a total of 109 scorable bands from genotypes of S. molle, out of which $23.0(21.1 \%)$ were found to be polymorphic, $1.00(0.91 \%)$ to be monomorphic bands and $85.0(77.9 \%)$ to be unique bands. Primer Oligo 345, yielded the maximum number of bands (20.0 bands) while the lowest number of bands (3.00 bands) obtained from Primer Oligo 214. The percentage of polymorphism ranged from $0.00 \%$ (Primer Oligo 33 and Primer Oligo 214) to $57.1 \%$ (Primer Oligo 342). The maximum number of unique bands (17.0 bands) was recorded from Primer Oligo 33, while the lowest number of unique bands (3.00 bands) from the Primer Oligo 342 and Primer Oligo 214 (Table 2 and Fig. 2 Panel A).

The genetic similarity coefficients (Table 3 ) revealed that the maximum similarity value (89.9\%) was between population at $2250.6 \mathrm{~m}$ and population at $2175.0 \mathrm{~m}$, while the least similarity value $(72.5 \%)$ between population at $2246.0 \mathrm{~m}$ and population at $2372.0 \mathrm{~m}$.

Dendrogram analysis (Fig. 3 Panel A) showed that population at 2193.0, 2197.7 and $2441.0 \mathrm{~m}$ found to be forming one cluster whereas population at $2246.0 \mathrm{~m}$ separated from them in a single cluster while population at 2372.0, 2250.6 and $2175.0 \mathrm{~m}$ found to be forming another one cluster.

Table 2. Polymorphism of eight RAPD primers.

\begin{tabular}{lccccc}
\hline Primer ID & $\begin{array}{c}\text { Total no. of } \\
\text { bands per } \\
\text { primer }\end{array}$ & $\begin{array}{c}\text { No. of } \\
\text { polymorphic } \\
\text { bands }\end{array}$ & $\begin{array}{c}\text { No. of } \\
\text { monomorphic } \\
\text { bands }\end{array}$ & $\begin{array}{c}\text { No. of } \\
\text { unique } \\
\text { bands }\end{array}$ & $\begin{array}{c}\text { Polymorphism } \\
\%\end{array}$ \\
\hline Oligo342 & 7.00 & 4.00 & 0.00 & 3.00 & 57.1 \\
Oligo 345 & 20.0 & 7.00 & 0.00 & 13.0 & 35.0 \\
Oligo 349 & 17.0 & 5.00 & 1.00 & 11.0 & 29.4 \\
Oligo 33 & 17.0 & 0.00 & 0.00 & 17.0 & 0.00 \\
OPK-8 & 19.0 & 3.00 & 0.00 & 16.0 & 15.7 \\
OPJ-1 & 13.0 & 1.00 & 0.00 & 12.0 & 7.69 \\
Oligo 214 & 3.00 & 0.00 & 0.00 & 3.00 & 0.00 \\
Oligo 213 & 13.0 & 3.00 & 0.00 & 10.0 & 23.0 \\
Total & 109 & 23.0 & 1.00 & 85.0 & 20.9 \\
\hline
\end{tabular}

\section{Mixed RAPD analysis}

Mixed RAPD primers generated a total of 100 reproducible bands of which (19.0\%) were polymorphic bands, (81.0\%) unique bands, and no any monomorphic bands (Table 4 and Fig. 2 Panel B). Primer OPK-8 produced the highest number of bands (21.0) while primer Oligo 42 gave the minimum number of bands (3.00). Primer Oligo 33 showed the highest percentage value of polymorphism of $50.0 \%$ and the zero polymorphism rate gained from the primer Oligo 42 and 
primer Oligo 214. The maximum number of unique bands were (18.0 bands) gained from primer OPK-8, while the minimum numbers were (3.00) gained from primer Oligo 42.

Table 3. Genetic similarity among $S$. molle plants based on RAPD markers.

\begin{tabular}{llllllll}
\hline & $2193.0 \mathrm{~m}$ & $2246.0 \mathrm{~m}$ & $2197.7 \mathrm{~m}$ & $2441.0 \mathrm{~m}$ & $2372.0 \mathrm{~m}$ & $2250.6 \mathrm{~m}$ & $2175.0 \mathrm{~m}$ \\
\hline $2193.0 \mathrm{~m}$ & 1.00 & & & & & & \\
$2246.0 \mathrm{~m}$ & 0.7614 & 1.00 & & & & & \\
$2197.7 \mathrm{~m}$ & 0.8216 & 0.7821 & 1.00 & & & & \\
$2441.0 \mathrm{~m}$ & 0.7956 & 0.7684 & 0.828 & 1.00 & & & \\
$2372.0 \mathrm{~m}$ & 0.7399 & 0.7251 & 0.7753 & 0.8022 & 1.00 & & \\
$2250.6 \mathrm{~m}$ & 0.8404 & 0.828 & 0.8705 & 0.8705 & 0.8821 & 1.00 & \\
$2175.0 \mathrm{~m}$ & 0.7471 & 0.7326 & 0.7821 & 0.7956 & 0.7821 & 0.899 & 1.00 \\
\hline
\end{tabular}

The genetic similarity coefficients displayed the highest similarity value (87.6\%) between population at $2246.0 \mathrm{~m}$ and population at $2197.7 \mathrm{~m}$, while the least similarity value (72.6\%) was recorded between population at $2372.0 \mathrm{~m}$ and population at $2175.0 \mathrm{~m}$ (Table 5).

Resulted dendrogram showed that populations at 2193.0, 2246.0 and $2197.7 \mathrm{~m}$ found to be forming one cluster whereas population at $2441.0 \mathrm{~m}$ and population at $2372.0 \mathrm{~m}$ clustered together as well as population at $2250.6 \mathrm{~m}$ and population at $2175.0 \mathrm{~m}$ (Fig. 3 Panel B).

Table 4. Polymorphism of eight mixed RAPD primers.

\begin{tabular}{lccccc}
\hline Primer ID & $\begin{array}{c}\text { Total no. of } \\
\text { bands per } \\
\text { primer }\end{array}$ & $\begin{array}{c}\text { No. of } \\
\text { polymorphic } \\
\text { bands }\end{array}$ & $\begin{array}{c}\text { No. of } \\
\text { monomorphic } \\
\text { bands }\end{array}$ & $\begin{array}{c}\text { No. of } \\
\text { unique } \\
\text { bands }\end{array}$ & $\begin{array}{c}\text { Polymorphism } \\
\%\end{array}$ \\
\hline Oligo 342 & 17.0 & 3.00 & 0.00 & 14.0 & 17.6 \\
Oligo 345 & 16.0 & 6.00 & 0.00 & 10.0 & 37.5 \\
Oligo 42 & 3.00 & 0.00 & 0.00 & 3.00 & 0.00 \\
Oligo 349 & 15.0 & 1.00 & 0.00 & 14.0 & 6.66 \\
Oligo 214 & 10.0 & 0.00 & 0.00 & 10.0 & 0.00 \\
Oligo 213 & 8.00 & 1.00 & 0.00 & 7.00 & 12.5 \\
Oligo 33 & 10.0 & 5.00 & 0.00 & 5.00 & 50.0 \\
OPK 8 & 21.0 & 3.00 & 0.00 & 18.0 & 14.2 \\
Total & 100 & 19.0 & 0.00 & 81.0 & 17.3 \\
\hline
\end{tabular}

\section{ISSR analysis}

A total of 231 counted bands were generated by using the nine ISSR primers from S. molle genetic materials (Table 6 and Fig. 2 Panel C). Sixty-two polymorphic bands (26.8\%), 1.00 (0.43\%) monomorphic bands, 168 (72.7\%) unique bands with polymorphism rate $23.2 \%$ were recorded. Primer UBC 826 generated the maximum number of bands (63.0), while primer UBC 824 showed the minimum number of bands (6.00). Primer (1) showed the highest rate of polymorphism (51.4\%) and Primer (3) showed the least rate numbers (4.54\%). The highest number of unique bands (46.0) was recorded from primer UBC 826, while the least number of unique bands (5.00) resulted from primer UBC 824. 
Resulted genetic similarity coefficients exhibited the highest similarity value among populations at $2193.0 \mathrm{~m}, 2246.0 \mathrm{~m}, 2441.0 \mathrm{~m}$ and population at $2250.6 \mathrm{~m}$ recording $86.2 \%$, while the least similarity value between population at $2246.0 \mathrm{~m}$ and population at $2175.0 \mathrm{~m}$ with value of $69.1 \%$ (Table 7 ).

A dendrogram pattern revealed that population at $2193.0 \mathrm{~m}$ and population at $2246.0 \mathrm{~m}$ formed one cluster whereas the populations at $2197.7 \mathrm{~m}, 2441.0 \mathrm{~m}, 2250.6 \mathrm{~m}$ and $2372.0 \mathrm{~m}$ found to be in another cluster and population at $2175.0 \mathrm{~m}$ formed out-group from the in-group including populations at $2193.0 \mathrm{~m}, 2246.0 \mathrm{~m}, 2197.7 \mathrm{~m}, 2441.0 \mathrm{~m}, 2250.6 \mathrm{~m}$ and $2372.0 \mathrm{~m}$ (Fig. 3 Panel C).

Table 5. Genetic similarity among $S$. molle plants based on mixed RAPD markers.

\begin{tabular}{llllllll}
\hline & $2193.0-\mathrm{m}$ & $2246.0-\mathrm{m}$ & $2197.7-\mathrm{m}$ & $2441.0-\mathrm{m}$ & $2372.0-\mathrm{m}$ & $2250.6-\mathrm{m}$ & $2175.0-\mathrm{m}$ \\
\hline $2193.0 \mathrm{~m}$ & 1.00 & & & & & & \\
$2246.0 \mathrm{~m}$ & 0.8701 & 1.00 & & & & & \\
$2197.7 \mathrm{~m}$ & 0.8439 & 0.8764 & 1.00 & & & & \\
$2441.0 \mathrm{~m}$ & 0.8235 & 0.8439 & 0.8571 & 1.00 & & & \\
$2372.0 \mathrm{~m}$ & 0.7654 & 0.7879 & 0.8024 & 0.8372 & 1.00 & & \\
$2250.6 \mathrm{~m}$ & 0.7952 & 0.7879 & 0.8166 & 0.8235 & 0.75 & 1.00 & \\
$2175.0 \mathrm{~m}$ & 0.7578 & 0.7654 & 0.8095 & 0.7879 & 0.7261 & 0.8166 & 1.00 \\
\hline
\end{tabular}

Table 6. Polymorphism of nine ISSR primers.

\begin{tabular}{lccccc}
\hline Primer ID & $\begin{array}{c}\text { Total no. of } \\
\text { bands per } \\
\text { primer }\end{array}$ & $\begin{array}{c}\text { No. of } \\
\text { polymorphic } \\
\text { bands }\end{array}$ & $\begin{array}{c}\text { No. of } \\
\text { monomorphic } \\
\text { bands }\end{array}$ & $\begin{array}{c}\text { No. of } \\
\text { unique } \\
\text { bands }\end{array}$ & $\begin{array}{c}\text { Polymorphism } \\
\%\end{array}$ \\
\hline Primer (3) & 22.0 & 1.00 & 0.00 & 21.0 & 4.54 \\
Primer (4) & 26.0 & 5.00 & 0.00 & 21.0 & 19.2 \\
UBC 823 & 18.0 & 5.00 & 0.00 & 13.0 & 27.7 \\
UBC 824 & 6.00 & 1.00 & 0.00 & 5.00 & 16.6 \\
UBC 826 & 63.0 & 16.0 & 1.00 & 46.0 & 25.3 \\
HB 14 & 30.0 & 12.0 & 0.00 & 18.0 & 40.0 \\
Primer (1) & 35.0 & 18.0 & 0.00 & 17.0 & 51.4 \\
Primer (2) & 20.0 & 3.00 & 0.00 & 17.0 & 15.0 \\
HB 11 & 11.0 & 1.00 & 0.00 & 10.0 & 9.09 \\
Total & 231 & 62.0 & 1.00 & 168 & 23.2 \\
\hline
\end{tabular}

Table 7.Genetic similarity among $S$. molle plants based on ISSR markers.

\begin{tabular}{llllllll}
\hline & $2193.0 \mathrm{~m}$ & $2246.0 \mathrm{~m}$ & $2197.7 \mathrm{~m}$ & $2441.0 \mathrm{~m}$ & $2372.0 \mathrm{~m}$ & $2250.6 \mathrm{~m}$ & $2175.0 \mathrm{~m}$ \\
\hline $2193.0 \mathrm{~m}$ & 1.00 & & & & & & \\
$2246.0 \mathrm{~m}$ & 0.8621 & 1.00 & & & & & \\
$2197.7 \mathrm{~m}$ & 0.8123 & 0.8123 & 1.00 & & & & \\
$2441.0 \mathrm{~m}$ & 0.8093 & 0.7906 & 0.8304 & 1.00 & & & \\
$2372.0 \mathrm{~m}$ & 0.7969 & 0.7713 & 0.7874 & 0.8392 & 1.00 & & \\
$2250.6 \mathrm{~m}$ & 0.8093 & 0.7713 & 0.8304 & 0.8621 & 0.8333 & 1.00 & \\
$2175.0 \mathrm{~m}$ & 0.7273 & 0.6912 & 0.7514 & 0.7411 & 0.7131 & 0.7874 & 1.00 \\
\hline
\end{tabular}


Super tree analysis (RAPD + mixed RAPD + ISSR)

A combined analysis using pooled RAPD, mixed RAPD and ISSR data showed that there are $20.5 \%$ polymorphism among studied population growing at various height. The highest similarity values (85.5\%) was found between populations at $2441.0 \mathrm{~m}$ and population at $2250.6 \mathrm{~m}$ and the lowest similarity values between population at $2246.0 \mathrm{~m}$ and population at $2175.0 \mathrm{~m}(71.9 \%)$ Table (8). Resulted dendrogram revealed that population at 2193.0-m and population at 2246.0-m clustered together whereas populations at 2197.7, 2441.0, 2250.6 and $2372.0 \mathrm{~m}$ found to be forming one cluster while population at $2175.0 \mathrm{~m}$ separated from them in a single cluster (Fig. 3 Panel D).

Table 8. Genetic similarity among $S$. molle plants based on combined analysis.

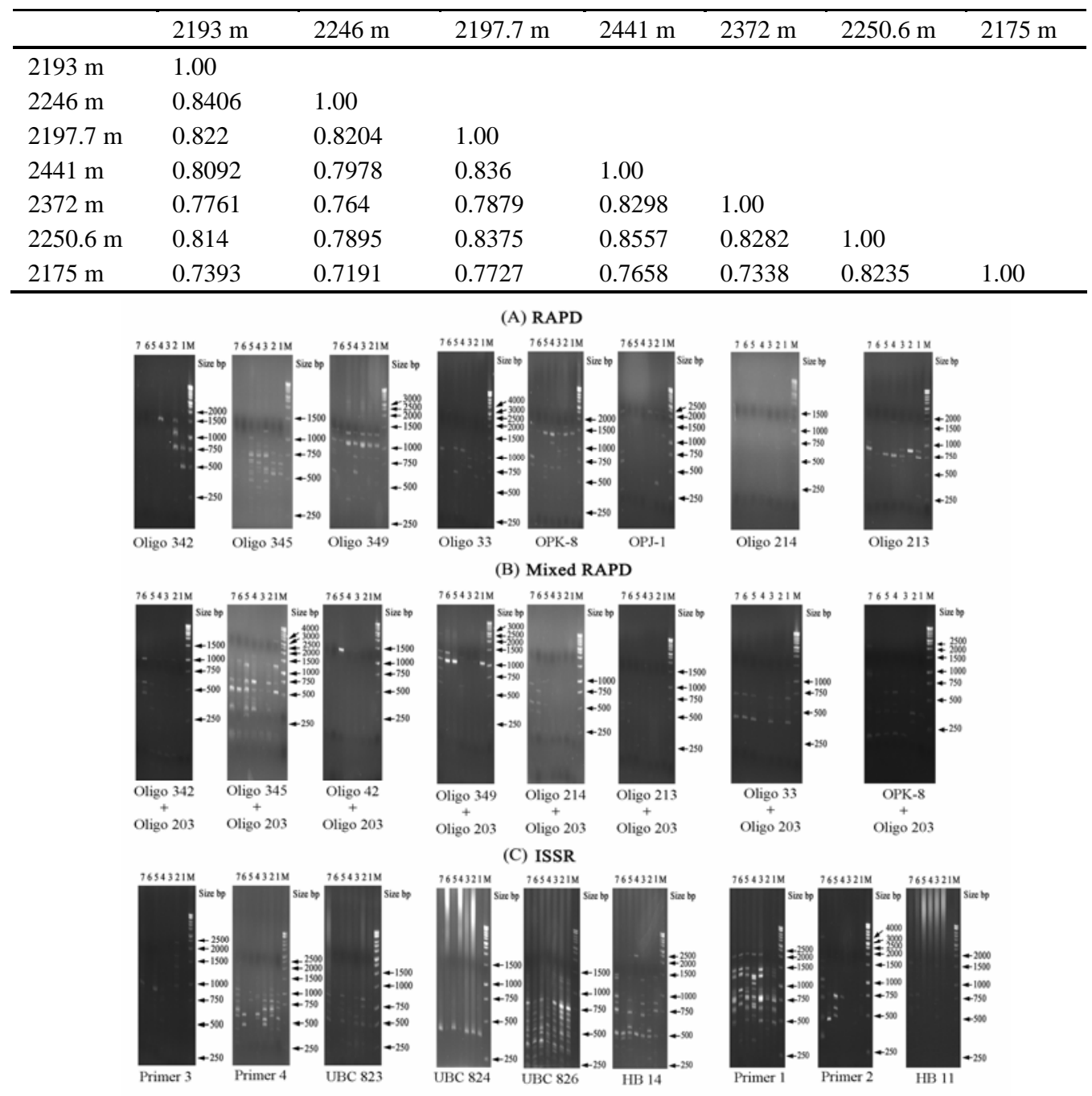

Fig. 2. RAPD, mixed RAPD and ISSR profiles of S. molle plants. Lane 1, 2193.0; Lane 2, 2246.0; Lane 3, 2197.7; Lane 4, 2441.0; Lane 5, 2372.0; Lane 6, 2250.6; Lane 7, 2175.0; M-1kb DNA Ladder. 
(A) RAPD

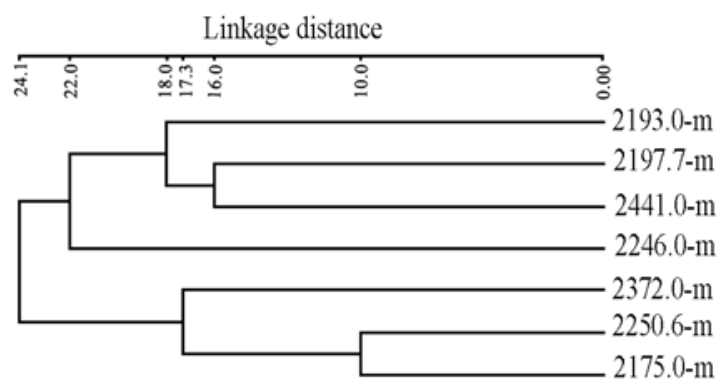

(B) Mixed RAPD
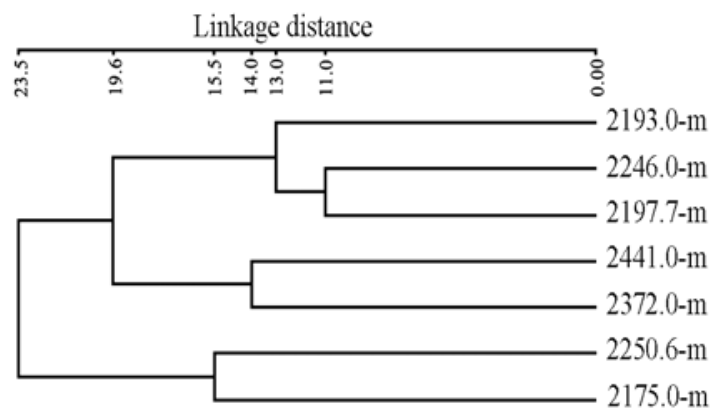

(C) ISSR

Linkage distance

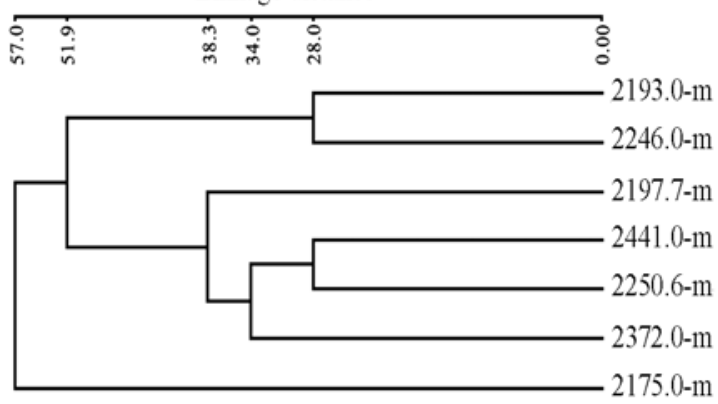

Linkage distance

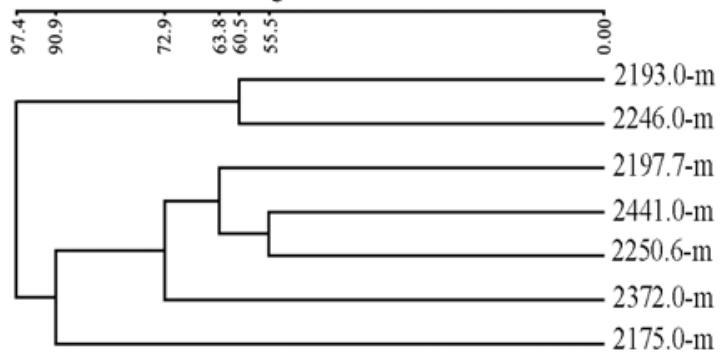

Fig. 3.Dendrogram based on RAPD, mixed RAPD, ISSR and super tree data of S. molle. 


\section{Discussion}

This research article reports the use of the RAPD, mixed RAPD and ISSR makers to the $S$. molle plant and revealed its efficiency to determinate the DNA fingerprints. Also it revealed that RAPD, mixed RAPD and ISSR markers could be used alone or in combination to estimate the genetic diversifications of $S$. molle plants. Polymorphism rate obtained either from RAPD, mixed RAPD, ISSR or from combined analysis all showed that there was high genetic variability among S. molle at a very close distance populations. The percentage of polymorphism almost same to that detected in other examined plants that they have a wide genetic variability. For example, Adawy et al. (2004) and Hussein et al. (2005) found that RAPD polymorphism rate in various Egyptian date palm cultivars (Phoniex dactylifera L.) is in the range of $25.2 \%$ and for ISSR technique in the range of 28.6\%. Among the studied Pistacia vera (L.) various cultivars polymorphism rate based on ISSR markers was $46.4 \%$ and $100 \%$ among Mangifera indica (L.) based on ISSR markers (Noroozi et al., 2009; Souza et al., 2011). RADP, mixed RAPD and ISSR showed various degrees in their ability to detect the diversifications among populations of $S$. molle plants. This variation may be due to that the genome $S$. molle plants having a considerable number of alleles per locus/or loci that vary in their distribution. Izzatullayeva et al. (2014) reported that such difference between RAPD and ISSR markers due to the fact of abundant nature of microsatellites that results from slippage in DNA replication. This explains why this plant can be found in various habitats vary from salinity soil to alkalinity soil and in different temperature condition ranging from very low to very high (Lim, 2012). In this study, total number of unique bands obtained from ISSRPCR of S. molle plant more than that of RAPD-PCR and mixed RAPD-PCR. The results also showed that ISSR fingerprinting had a high number of scored bands and high polymorphic percentage rate. This in agreement with earlier studies showed that ISSR fingerprinting was more efficient than the RAPD assay in assessing genetic variation in Arthrocnemum macrostachyum (Saleh, 2011). Again this variation among RAPD, mixed RAPD and ISSR probably due to that amplified profiles of PCR of RAPD, ISSR, or mixed RAPD originated from different variable numbers of repetitive and non-repetitive sequence on the genomes of $S$. molle plant (Thormann et al., 1994). The presence of monomorphic bands from RAPD-PCR or from ISSR-PCR indication to the sharing characters based on the DNA fragment in genomic $S$. molle plants. Cluster analysis based on RAPD, mixed RAPD and ISSR markers individually or combined showed that the three markers differ from each other in the manner of distributing $S$. molle populations.

In our study, the amount of genetic similarity among various populations of $S$. molle plants based on RAPD markers were in range between $72.5 \%$ to $89.9 \%$ and for mixed RAPD between $72.6 \%$ to $87.6 \%$ and for ISSR $69.1 \%$ to $86.2 \%$ and for the sum of all data between $71.9 \%$ to 85.5\%. These values to some extent are in accordance with the basis proofed by Weier et al. (1982) that operational taxonomic units between 85 to $100 \%$ among the same plant species and more than $65 \%$ between the same plant genus. In conclusion, our study confirms that there were a wide genetic diversity among $S$. molle plants that can be evaluated by using RAPD, mixed RAPD and ISSR markers.

\section{Acknowledgements}

The authors are thankful to King Abdul-Aziz City for Science and Technology (KACST) for providing financial support (No.AT-36-305).

\section{References}


Adawy, S.S., Hussein, E.H.A., El-Khishin, D., Saker, M.M., Mohamed, A.A. and El-Itriby, H.A. 2004. Genotyping Egyptian date palm cultivars using RAPD, ISSR, AFLP markers and estimation of genetic stability among tissue culture derived plants. Arab J. Biotech.8: 99-114.

Doganlar, Z. B., Doganlar, O., Erdogan, S. and Onal, Y. 2012. Heavy metal pollution and physiological changes in the leaves of some shrub, palm and tree species in urban areas of Adana, Turkey. Chem Spec Bioavailab 24: 65-78.

Fikiru, E., Tesfaye, K. and Bekele, E. 2007. Genetic diversity and population structure of Ethiopian lentil (Lens culinaris Medikus) landraces as revealed by ISSR marker. Afr. J. Biotechnol. 6: 1460-1468.

Hashemi, S.H., Mirmohammadi-Maibody, S.A.M., Nematzadeh G.A. and Arzani, A. 2009. Identification of rice hybrids using microsatellite and RAPD markers. Afr. J. Biotechnol. 8: 2094-2101.

Hussein, E.H.A., Adawy, S.S., Ismail, S.E.M.E. and El-Itriby, H.A. 2005. Molecular characterization of some Egyptian date palm germplasm using RAPD and ISSR markers. Arab J. Biotechn. 8: 83-98.

Izzatullayeva, V., Akparov, Z., Babayeva, S., Ojaghi, J. and Abbasov, M. 2014. Efficiency of using RAPD and ISSR markers in evaluation of genetic diversity in sugar beet. Turk. J. Biol. 38: 429-438.

Lim, T.K. 2012. Edible medicinal and non-medicinal plants: volume 1, fruits: Schinus molle. Springer, Netherlands, 153-159 pp.

Moustafa, M.F., Hesham, A., Quraishi, M.S. and Alrumman S.A. 2016. Variations in genetic and chemical constituents of Ziziphus spina-christi L. populations grown at various altitudinal zonation up to $2227 \mathrm{~m}$ height.Genet. Eng. Biotechnol. 14: 349-362.

Noroozi, S., Baghizadeh, A. and Javaran, M.J. 2009. The genetic diversity of Iranian pistachio (Pistacia vera L.) cultivars revealed by ISSR markers. Bio Di Con. 2: 50-56.

Olafsson, K., Jaroszewski, J.W., Smitt, U.W. and Nyman, U. 1997. Isolation of angiotensin converting enzyme (ACE) inhibiting triterpenes from Schinusmolle. Planta Med. 63: 352-355.

Pereira, M. P., Rodrigues, L. C. A., Corrêa, F. F., Castro, E. M., Ribeiro, V. E. and Pereira, F. J. 2016. Cadmium tolerance in Schinus molle trees is modulated by enhanced leaf anatomy and photosynthesis. Trees30: 807-814.

Saleh, B. 2011. Efficiency of RAPD and ISSR markers in assessing genetic variation in Arthrocnemum macrostachyum (Chenopodiaceae). Braz. Arch. Biol. Technol. 54: 859-866.

Sneath, P.H.A. and Sokal, R.R. 1973. Numerical taxonomy: the principles and practice of numerical classification. W.H. Freeman and Company, San Francisco, California, CA, USA.

Souza, I.G.B., Valente, S.E.S., Britto, F.B., de Souza, V.A.B. and Lima, P.S.C. 2011. RAPD analysis of the genetic diversity of mango (Mangifera indica) germplasm in Brazil. Genet. Mol. Res. 10: 3080-3089.

Thormann, C.E., Ferreira, M.E., Camargo, L.E.A., Tivang, J.G. and Osborn, T.C. 1994. Comparison of RFLP and RAPD Markers to Estimating Genetic Relationships Within and Among Cruciferous Species. Theor Appl Genet 88: 973-980.

Uyoh, E.A., Umego, C. and Aikpokpodion, P.O. 2014. Genetic diversity in African ntmeg (Monodora myristica) a ccessions from South Eastern Nigeria. Afr. J. Biotechol. 13: 4105-4111.

Vieira, R.F., Goldsbrough, P. and Simon, J.E. 2003. Genetic diversity of basil (Ocimum spp.) based on RAPD markers. J. Amer. Soc. Hort. Sci. 128: 94-99.

Weier, T.E., Stocking, C.R., Barbour, M.G. and Rost, T.L. 1982. Botany: an Introduction to Plant Biology. John Wiley and Sons, New York.

Wu, C., Zhong, C., Zhang, Y., Jiang, Q., Chen, Y., Chen, Z., Pinyopusarerk, K. and Bush, D. 2014. Genetic diversity and genetic relationships of Chukrasia spp. (Meliaceae) as revealed by inter simple sequence repeat (ISSR) markers. Trees 28: 1847-1857.

(Manuscript received on 6 June 2016; revised on 28 October 2017) 